\title{
Nanotechnology Development for Formulating Essential Oils in Wound Dressing Materials to Promote the Wound-Healing Process: A Review
}

\author{
Ilenia De Luca ${ }^{1,+}+\mathbb{D}$, Parisa Pedram ${ }^{2,3,+}$, Arash Moeini ${ }^{4}\left(\mathbb{D}\right.$, Pierfrancesco Cerruti $^{5}$, Gianfranco Peluso ${ }^{6}$, \\ Anna Di Salle ${ }^{6}$ (D) and Natalie Germann ${ }^{4, *}$
}

check for updates

Citation: De Luca, I.; Pedram, P.; Moeini, A.; Cerruti, P.; Peluso, G.; Di Salle, A.; Germann, N.

Nanotechnology Development for Formulating Essential Oils in Wound Dressing Materials to Promote the Wound-Healing Process: A Review. Appl. Sci. 2021, 11, 1713.

https://doi.org/10.3390/app11041713

Academic Editor: Won Ho Park

Received: 22 December 2020

Accepted: 5 February 2021

Published: 14 February 2021

Publisher's Note: MDPI stays neutral with regard to jurisdictional claims in published maps and institutional affiliations.

Copyright: (c) 2021 by the authors. Licensee MDPI, Basel, Switzerland. This article is an open access article distributed under the terms and conditions of the Creative Commons Attribution (CC BY) license (https:/ / creativecommons.org/licenses/by/ $4.0 /)$.
1 Elleva Pharma S.R.L. Via Pietro Castellino, 111, 80131 Naples, Italy; ilenia.deluca@ellevapharma.com

2 Department of Chemical, Materials and Industrial Production Engineering, University of Naples Federico II, 80138 Napoli, Italy; parisa.pedram@iit.it

3 Center for Advanced Biomaterials for Healthcare, Istituto Italiano di Tecnologia (IIT@CRIB), 80125 Naples, Italy

4 Fluid Dynamics of Complex Biosystems, School of Life Sciences Weihenstephan, Technical University of Munich, 85354 Freising, Germany; arash.moeini@tum.de

5 Institute for Polymers, Composites and Biomaterials (IPCB-CNR), Via Campi Flegrei 34, 80078 Pozzuoli, Italy; pierfrancesco.cerruti@cnr.it

6 Research Institute on Terrestrial Ecosystems (IRET) —CNR, Via Pietro Castellino 111, 80131 Naples, Italy; gianfranco.peluso@cnr.it (G.P.); anna.disalle@cnr.it (A.D.S.)

* Correspondence: natalie.germann@tum.de

+ These authors contributed equally to this work.

\begin{abstract}
Wound healing refers to the replacement of damaged tissue through strongly coordinated cellular events. The patient's condition and different types of wounds complicate the already intricate healing process. Conventional wound dressing materials seem to be insufficient to facilitate and support this mechanism. Nanotechnology could provide the physicochemical properties and specific biological responses needed to promote the healing process. For nanoparticulate dressing design, growing interest has focused on natural biopolymers due to their biocompatibility and good adaptability to technological needs. Polysaccharides are the most common natural biopolymers used for wound-healing materials. In particular, alginate and chitosan polymers exhibit intrinsic antibacterial and anti-inflammatory effects, useful for guaranteeing efficient treatment. Recent studies highlight that several natural plant-derived molecules can influence healing stages. In particular, essential oils show excellent antibacterial, antifungal, antioxidant, and anti-inflammatory properties that can be amplified by combining them with nanotechnological strategies. This review summarizes recent studies concerning essential oils as active secondary compounds in polysaccharide-based wound dressings.
\end{abstract}

Keywords: polysaccharides; wound dressing; essential oils; nanotechnology; wound healing; antimicrobial; antioxidant

\section{Introduction}

Wound healing is a complex process that depends on internal and external conditions. Therefore, the acceleration of wound treatment must involve promoting the healing process. The general care procedure involves removing the infection from the wound bed and then applying the wound dressing [1]. There are two kinds of wounds that result from injury by cutting, hitting, and burning: open and closed wounds [2]. Open wounds are usually accompanied by bleeding and are associated with rupturing layers of the skin [3-5]. Closed wounds result from bruising or dead blood and crashes. In terms of clinical features, wounds are divided into acute and chronic wounds. Acute wounds are caused by burns, cuts, and surgical incisions, and their healing process takes 8-12 weeks [6]. Chronic wounds 
are due to tumors, bed wounds, and diabetic wounds, which lead to extended inflammation and a more prolonged healing time.

The wound-healing processes can be divided into four successive stages: homeostasis, inflammation, proliferation, and remodeling (Figure 1). The first healing stage is hemostasis, which begins with the cessation of bleeding. When a part of the body bleeds, the first step is to start the hemostasis phase, and the blood vessels contract, which reduces the bleeding [6]. In this situation, platelets then stick together to cover the damaged vascular wall, and coagulation occurs. Many platelets stick together with fibrin glue, which traps red blood cells like a net and stops bleeding. The process of homeostasis occurs very quickly. After that, the first fibrin scaffold is formed in $60 \mathrm{~s}$ with fibrin glue, which turns from a liquid to jelly to form a blood clot and releases prothrombin. The thrombus retains platelets, clots, or blood cells in the wound area [7]. Inflammation is the second phase in wound healing and occurs right after the blood vessels are damaged and blood is leaking. Inflammation both controls bleeding and prevents infection. During this phase, white blood cells, growth factors, nutrients, and enzymes move toward the injured area, which leads to swelling, redness, pain, and various inflammatory stages. Inflammation is a natural part of the wound-healing process and only extends the healing process of the wound [8]. The next stage is proliferation, which begins when new tissue regenerates in the wound. In this step, the new tissue is formed with extracellular matrix (ECM) and collagen. A new network of blood vessels and healthy granular tissue is fabricated with adequate oxygen supply and proper nutrition $[9,10]$. The last phase is remodeling, which occurs by converting collagen type III to collagen type I when the wound is completely closed. In this stage, collagen is reabsorbed along the squeezing lines, which leads to the attachment of collagen fibers and an improvement in the new tissue's tensile strength [7,11-13].

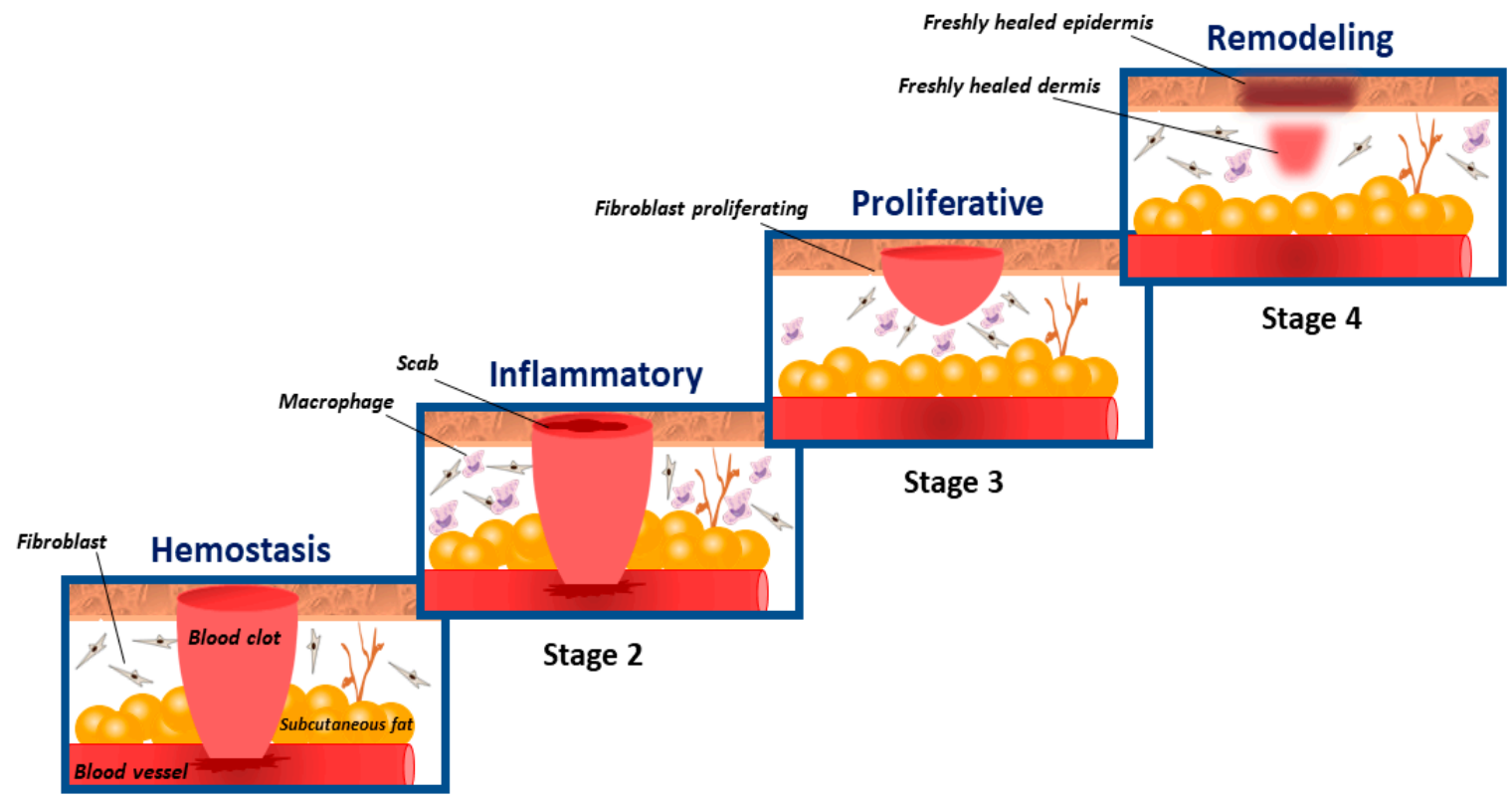

Stage 1

Figure 1. Different stages of the wound-healing process.

Due to the complexity of the wound-healing process, selecting a suitable wound dressing for the wound type is indispensable. An ideal wound dressing should improve the healing process by eliminating excessive exudate, promoting autolytic debridement, retaining adequate moisture for healing, and providing the least inconvenience for the patient $[14,15]$. Simultaneously, a wound dressing should allow faster healing without being too expensive [16,17]. However, conventional dressings are mostly dry and challenging to apply. Furthermore, traditional methods for treating chronic wounds cannot heal $70 \%$ of patients, including dermal substitutes, human skin equivalents, and recombinant growth 
factors from human platelets [18]. To overcome these drawbacks, active wound dressing has been developed by incorporating active agents in wound dressing materials to prevent microorganisms from infecting the wound [14].

Natural biopolymers have recently been used as wound dressing materials because of their biocompatibility, biodegradability, and similarity to the ECM [19]. Studies show that they can be promising for replacing conventional wound dressing materials because of their remarkable biocompatibility, biodegradability, and good physicochemical properties [15]. The common biopolymers for wound dressing applications are proteins, collagen, gelatin, silk fibroin, alginate, hyaluronic acid, chitosan, and fucoidan poly-N-acetyl glucosamine [20-25]. Chitosan and alginate have intrinsic antibacterial and anti-inflammatory properties [26-30]. The improvement of dressings using nanotechnology has been inspired by the lack of adequate physicochemical properties and specific biological responses of classical materials for wound treatment [31]. Nanotechnology consists of manipulating materials at nanoscale levels and is widely employed in various fields of medicine, engineering, and electronics [32]. It can be a strategy to promote wound healing by intervening in the healing phases [31].

Essential oils (EOs) such as monoterpenes and sesquiterpenes are low-molecularweight secondary metabolites from plants. Because of flavor, aroma, and antimicrobial properties, they are used in various fields such as agriculture [33], medicine [34,35], wound healing $[14,36]$, cosmetics $[37,38]$, pharmaceuticals, tissue engineering to develop skin scaffolds [39-43], and the food packaging industry [44-51]. Depending on the functional groups, the EOs may be more or less hydrophobic in nature, which must be taken into account when incorporating them into a specific polymer matrix. Successful formulation can be demonstrated by various standard techniques such as FTIR, UV-vis, ${ }^{1} \mathrm{HNMR}$, thermogravimetric analysis (TGA), differential scanning calorimetry (DSC), and X-ray diffraction (XRD) [47,48]. With regard to wound healing and medical applications, secondary compounds have traditionally been used in folk medicine for wound treatment. Data suggest that $8 \%$ worldwide still use herbal remedies as natural medicine [52].

Antimicrobial action is a current focus in wound dressing and biomedical devices in general. The antimicrobial wound dressing can be intrinsic, with the dressing material itself, or can be engineered with antimicrobial molecules by adding an antibiotic agent to a polymer backbone or in the form of nanoparticles or chemicals linked to a polymer surface $[52,53]$. Many studies and reviews have reported on active wound dressings manufactured using antimicrobial and antibiotic metal nanoparticles. However, recently, researchers have paid attention to active natural antimicrobial and antioxidant agents from plants. Therefore, in this review, we overview the recent studies related to incorporating essential oils as active secondary compounds in biopolymer-based formulations using nanotechnology and its influence on the wound-healing process (Figure 2). 


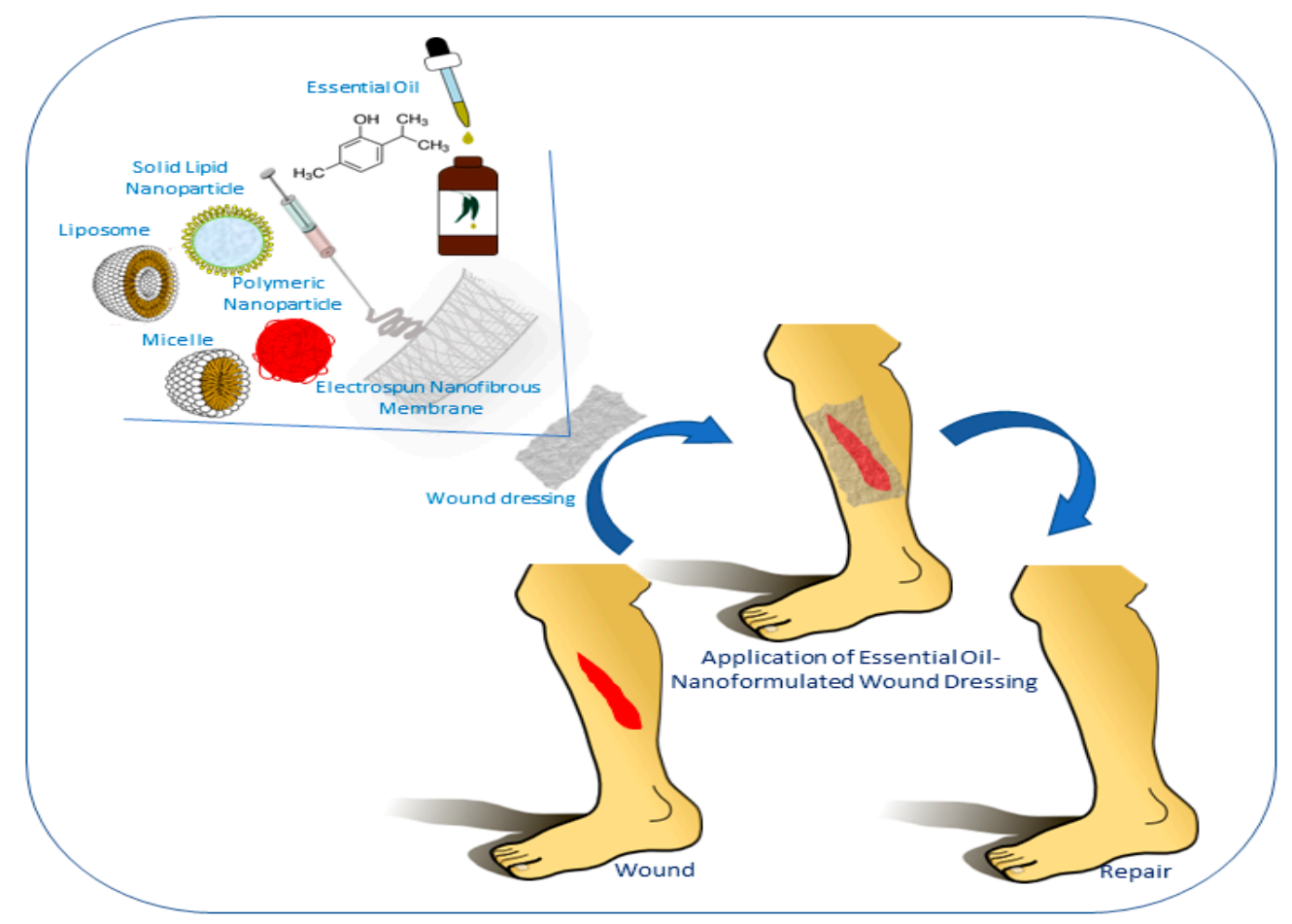

Figure 2. A diagram of wound tissue repair using nanomaterials loaded with essential oils at a target site.

\section{Biopolymers in Wound Dressings}

Wound dressings are used to protect wounds and accelerate the healing process. Thus, it is necessary to develop an appropriate wound dressing system [54]. Proper wound dressing materials must be flexible, biodegradable, and have an adequate gas barrier to decrease the infection rate [14]. Other significant parameters are the adhesive ability and the capability of controlling the absorbance of exudates in a wounded area [55]. Traditional dressings like woven or nonwoven gaze are the most common wound dressing system. They are applied in the first step of the healing process to prevent bleeding and protect the wound from the environment. A major disadvantage if these traditional dressings is that they promote desiccation in wounds with minimal exudate unless used in combination with another dressing or topical agent. Semisolid materials such as ointments, creams, and gels can be used alone or in combination with a protecting cover [56-60]. They can easily fill wound cavities as a result of their flowable properties and support the maintenance of a physiological moist environment [14,61-64]. Other forms of wound dressings include transparent films ranging from $\mu \mathrm{m}$ to $\mathrm{mm}$ in thickness to flexibly cover the wounds [65-68]. An optimal wound dressing material must appropriately respond to the wound target's characteristics, such as its size and exudate amount.

Nowadays, natural biopolymers are extensively used for wound treatment because of their compatibility with the human organism. Furthermore, they show good adaptability to technological needs due to their easy chemical modification with derivatives [69]. The most common natural biopolymers applied for wound healing are polysaccharides (cellulose, alginates, chitosan, heparin, hyaluronic acid, and chondroitin), proteoglycans, and proteins (collagen, gelatin, fibrin, keratin, silk fibroin, and eggshell membrane) $[16,53,70]$. They have been selected based on their biodegradability and inherent cellular interaction, and closeness to the structure and surface topography of the ECM [52]. Their enzymatic degradation, which principally occurs if biopolymers are not crosslinked, releases welltolerated byproducts [69]. Moreover, it is well known that engineered natural biopolymers can respond to physiological signals and release growth factors or related molecules to reproduce the natural healing mechanism [71]. 
For example, cellulose dressings seem to release epidermal growth factor and basic fibroblast growth factor at their application site, stimulating wound closure. They can mitigate pain and control the granulation and epithelialization processes, allowing tissue regeneration [72,73]. Nanocellulose has also been used as a dressing biomaterial since it exhibits anti-infectious features, and in the form of a scaffold, it improves tensile properties [74]. Chitosan is a de-acetylated derivative of chitin, which is the principal constituent of the exoskeleton of insects, crustaceans, and arachnids and is similar in structure to cellulose. It is a cationic linear polysaccharide that contains D-glucosamine and N-acetyl glucosamine units. Its electrostatic behavior induces the activation of early-phase reaction pathways related to accelerated wound-healing mechanisms by triggering collagen synthesis and fibroblast growth, inducing the activation of the cytokine interleukin-8. The wide use of chitosan in dressings is mostly related to its antimicrobial, non-antigenic, and filmforming features [70]. Besides, chitosan shows other advantages, such as tensile strength, easy applicability, water sorptivity, oxygen permeability, and hemostatic action [75,76]. Another nonimmunogenic polysaccharide is alginate, which originates from brown algae. It exists in two forms: calcium and calcium sodium salts of alginic acid. A hydrophilic gel of sodium alginate forms from the ionic exchange between alginate calcium and sodium salts in wounds. This reaction induces the absorption of fluid at the wound site, which maintains moist conditions. Furthermore, alginate dressings can be easily removed and show hemostatic and flexibility properties [16,77]. The swelling capability of biopolymers is a necessary characteristic to allow exudate absorption and preserve hydration at the wound site.

\section{Nanotechnology in Wound Dressings}

Nanomaterials are useful agents for accelerating the wound-healing process due to their advantageous ratio of surface area to volume and drug delivery capability. This feature can influence collagen deposition and skin tissue regeneration. Specifically, the nanoparticles' dimensions allow them to penetrate into the wound, which allows for specific target molecules in wounds to be contacted and for bioactive agents or drugs to be released locally, which influences the healing progress $[78,79]$. The encapsulation of drugs into nanocarriers protects them from attack by wound-bed proteases, so they can carry out their biological action. Moreover, nanomaterials target specificity and controlled release into the site of interest decrease the number of therapeutic administrations and the possible risks due to high dose drug [80]. In general, the biological effects of bionanomaterials suitable for enhancing the wound-healing process refer to antibacterial and anti-inflammatory actions and the capability to influence ECM synthesis, stem cell proliferation, differentiation, and growth factors [81,82].

\subsection{Major Architectures of Nanomaterials}

Nanoemulsions, biphasic dispersions of two nonmiscible liquids, are among the most common types nanomaterials used for wound treatment. They show small droplet size, long shelf life, and simple synthesis processes, but their pharmacokinetics and pharmacodynamics are affected by the type of route of administration [83].

Nanoparticles generally refer to nanospheres, nanocapsules, solid lipid nanoparticles (SLNs), as well as nanostructures lipid carriers (NLCs). Nanocapsules consist of biopolymers containing a core of lipidic/lipophilic molecules. Their feature is the capability to release their cargo safely and enhance its diffusion into deeper skin layers. However, their efficacy can be compromised by a large amount of substance being directly administered on the skin.

Nanospheres are usually made of poly(lactic-co-glycolic acid) (PLGA) and chitosan as colloidal systems useful for delivering proteins and peptides involved in wound healing. However, their loading capacity is low, and the release is characterized by a kinetic burst. Protein administration can also be obtained by SLNs using a topical route. 
NCLs exhibit good efficiency, safety, and sustained drug release, but they have a low drug-loading capacity. They are similar in structure to liposomes, but they accommodate synthetic non-ionic surfactants. They exhibit specific target recognition thanks to the expression of surface receptors. This characteristic improves their effectiveness and reduces side effects.

Metal nanoparticles have antibacterial properties, low penetration into the skin, and transparency after application. However, some physicochemical and biological have to be improved. For these reasons, metal and metal oxides nanoparticles, such as zinc and gold nanoparticles, are preferred. They have toxicity related to their size, so the synthesis process must be strongly controlled [84,85].

Polymeric nanoparticles represent architectures where the active molecule is embedded in the polymeric matrix and/or absorbed on its surface. They are used in versatile systems for wound dressings and delivery vehicles [86]. The degradation of polymeric nanoparticles is progressive and occurs in situ, and their products are metabolized by the host, allowing them to avoid additional surgical intervention [18]. Another advantage of using polymeric nanoparticles is regulating the release mechanism of a bioactive molecule from its matrix by choosing the right type of polymer and synthesis method [87].

\subsection{Synergistic Actions between Nanoparticles and Wound Dressing Matrix}

The combination of nanoparticles with a specific matrix allows synergistic actions. Polymeric hydrogels are widespread in wound dressings. Their porous structure can absorb large amounts of exudate, maintain moisture in the wound site, and permit oxygen permeation [88]. Gas exchange is an essential feature since it influences the wound site's acidity conditions, allowing bacteria colonization [89]. Moreover, hydrogels show physical properties similar to those of living tissue. A 3D hydrogel structure protects nanoparticles and their cargo from premature degradation to sustain a controlled response into the wound site. The properties responsible for nanohydrogels success are swelling, stimuli responsiveness, softness, and high biocompatibility. However, studies highlight their deficiency in pharmacodynamic and pharmacokinetic aspects [88].

For the bioadhesiveness and resistance necessary for dressings, polymeric films and membranes are synthesized to guarantee mechanical flexibility. They are composed of natural polymers, such as alginate, hyaluronan, or vegetable oil, or synthetic ones, like polyvinyl alcohol, as well as mixtures of these. Biopolymers, such as collagen, allow for biomimetic and bioactivity features. To improve wound-healing effects, nanoparticles that are able to release bioactive molecules can be added to films during their synthesis [80]. Casting is the most commonly used technique to produce films. It consists of pouring a polymeric solution into a mold and then waiting for the evaporation of the organic solvent until the polymer dries [90]. However, this method has the disadvantage of obtaining dense structures with low permeability, leading to exudate accumulation and infection [80].

Several studies have focused on using nanofiber scaffolds for wound management due to their structural features and wound-healing potential. Biodegradable scaffolds similar to ECM are considered ideal dressings, and electrospinning is the best technique to produce them since it can create scaffolds made of uniform polymeric nanofibers with desired dimensions. Scaffolds show several properties such as biocompatibility, controlled porosity, and permeability. Furthermore, they allow cell attachment because of their microporous structure similar to ECM. The polymers most used to create scaffolds are collagen, chitosan, and non-degradable fibers, such as polylactic acid, poly (vinyl alcohol) (PVA), polyethylene, and polyurethane. These scaffolds can allocate bioactive molecules that release nanoparticles to enhance the wound-healing process, influence cell behavior, and inhibit infection [91]. Recently, to obtain better-performing dressings, multicomposite scaffolds have been designed. They consist of a mixture of different types of scaffolds and nanoparticles. This combination leads to the synthesis of multifunctional dressings. Composite dressings can be used as one or two layers that are adaptable for several wound 
types. They show good permeability, compliance, control of infection, and absorptive capacity, but they also have high costs and must be replaced once a day [92].

\subsection{Two Major Nanotechnological Preparatory Techniques Applied in Wound Dressing}

The nanoformulation strategy is a solution to preserve the therapeutic efficacy of essential oils while minimizing their physicochemical limitations. For this purpose, mainly large molecules (e.g., cyclodextrin) and polymers have been used as carriers [93]. As a delivery system for the pharmacological application of essential oils, nanoemulsions are gaining special attention because they are inexpensive and scalable [94]. In fact, the nanoemulsion method is a simple synthetic technique and is applied for a simple composition. Nanoemulsions are isotropic dispersed systems of two immiscible liquids formed by mixing oil and water and adding surfactant/cosurfactant to obtain a droplet size in the nanometer range [95]. Three essential parameters should be considered in the composition, method, and manufacturing conditions to obtain a stable formulation [95]. The emulsion of the two immiscible liquid phases can create an interfacial tension that can be controlled by the addition of surfactants, which allows the dispersion of the particles [96]. Nanoemulsions can be classified as water-in-oil $(\mathrm{W} / \mathrm{O})$ and oil-in-water $(\mathrm{O} / \mathrm{W})$ emulsions. $\mathrm{O} / \mathrm{W}$ nanoemulsions are mainly used in the pharmaceutical field because they are easily washed out and are often used in drug delivery systems. The preparation of nanoemulsions starts with the successive conversion of a macroemulsion into a nanometric form by applying ultrasonic emulsification, high-pressure homogenization and microfluidization as highenergy methods, phase inversion and self-emulsification as low-energy techniques [97]. Macroemulsions are thermodynamically more stable than nanoemulsions, but the nanometric size improves lipophilic molecules' loading capacity (like essential oils, natural compounds) [98] and reduces particles sedimentation by decreasing the gravity effect onto their surface [99]. Even if the use of essential oil nanoemulsion as a food biopreserver is more prevalent [100], their wound-healing potential is noteworthy. The development of all kinds of wound dressing also influences the design of essential oil nanoemulsions. Indeed, essential oil nanoemulsions are combined with biopolymers, such as chitosan, with recognized biological effects [101], or they are used to ameliorate another kind of wound dressings, such as hydrogel [102] or both situations, as chitosan/alginate films [103].

The three-dimensional architecture of electrospun nanofiber membranes has an excellent advantage for wound treatment by mimicking the ECM structure. The properties of electrospun nanofibers also improve the wound-healing progress. In particular, the size of nanofibers and their network promote gas exchange and alienation of bacteria, while their high surface-to-volume ratio supports the delivery of therapeutic molecules [104]. Moreover, electrospun membranes show good adaptability to wound shape compared to conventional dressings, and their surface can be functionalized to enhance their bioactivity [105]. In electrospinning, a positive high voltage is applied to a viscoelastic liquid droplet of the polymer solution, deforming it into a conical shape. A pump ejects the droplets as a jet from a metal needle attached to a syringe and deposits them as fibers on an anodically charged collector plate. During the process, the overlapping of the fibers gradually forms mats. The resulting electrospun fibers are influenced in their morphology and mechanical properties by several parameters associated with the process, such as the applied voltage, the distance between the needle and the collector, the viscosity and conductivity of the solution, the volatility of the solvent, and the molecular weight of the polymer [106]. In particular, the solvent properties and the collector geometry seem to influence the porosity of the electrospun fibers. Indeed, the volatility of the solvent can affect the fiber surface, and the boiling point of the solvents and nonsolvents used can create pores due to the phase separation phenomena that occur before or during the electrospinning process [107]. Chitosan, alginate, and cellulose are the most common polysaccharide-based biopolymers used for wound dressings [108]. In addition, various polymer solutions can be electrospun using the coaxial method, which consists of simultaneous deposition of multiple concentric needles [109]. This modification can be used to 
obtain a wound dressing based on two different types of polymer matrices such as sodium alginate and chitosan that interact with electrostatic force [110].

\section{Essential Oils as Active Secondary Compounds in Wound Dressings}

Secondary metabolites like other antibiotic chemical compounds, e.g., such as aminoglycosides [111], beta-lactams [112], glycopeptides [113], quinolones [114], sulphonamides [115], and tetracyclines $[116,117]$, can be used to control wound infections. The influence of natural antimicrobials on the wound-healing process could be explained by their effects on growth factors (epithelial cells, fibroblasts, vascular endothelial cells) as stimulators of wound cells and cellular mechanisms [118]. In other words, the antimicrobial compounds accelerate and promote skin regeneration by influencing cell migration and ECM deposition [119]. In vitro and in vivo evidence indicates antimicrobial and anti-inflammatory effects of secondary active metabolites in the wound-healing process $[8,14]$. Natural antimicrobial compounds defuse through bacteria cell walls and break their cell membranes by invading the bacteria's membrane phospholipids and lipids [120]. Active metabolites can also act as antioxidant agents and accelerate the wound-healing process by decreasing intracellular ROS production and controlling the rate of nitric oxide synthase [121,122]. Bioactive secondary metabolites of plants could be used for wound healing, including alkaloids, essential oils, flavonoids, tannins, terpenoids, saponin, fatty acids, and phenols [36]. These active compounds could improve the wound-healing process by influencing one of the healing stages through antibacterial, antifungal, antioxidant, and anti-inflammatory effects [123]. Many studies have been done on the potential application of essential oils and other secondary metabolites in wound-healing applications by incorporating them in dressing materials. Moreover, essential oils demonstrate the capacity to be used as both a solvent and active material, which improves the synthesis process's sustainability and safety. Table 1 gives an overview of the different types of essential oils that have been formulated into polysaccharide-based wound dressing systems using nanotechnologies and their bioassays.

Table 1. Essential oil applications for wound healing.

\begin{tabular}{|c|c|c|c|c|}
\hline Essential Oils & Wound Dressing System & Method & Bioassay & References \\
\hline $\begin{array}{c}\text { Cinnamon, clove, and } \\
\text { lavender oils } \\
\text { (Cinnamomum Syzygium } \\
\text { aromaticum and Lavandula) } \\
\text { or Lavender oil/ }\end{array}$ & $\begin{array}{l}\text { Sodium } \\
\text { alginate/polyvinyl alcohol } \\
\text { nanofibers (cotton gauze) }\end{array}$ & Electrospinning & Staphylococcus aureus & [124] \\
\hline $\begin{array}{l}\text { Clove, Mandarin, and } \\
\text { Niaouli oil } \\
\text { (Syzygium aromaticum, } \\
\text { Citrus reticulata and } \\
\text { Melaleuca quinquenervia) }\end{array}$ & $\begin{array}{l}\text { Sodium alginate film+ } \\
\text { silver nanoparticles }\end{array}$ & Nanocoating/casting & $\begin{array}{c}\text { E. coli, Staphylococcus aureus, } \\
\text { and Candida albicans }\end{array}$ & [125] \\
\hline $\begin{array}{l}\text { Eucalyptus essential oil (+ } \\
\text { Manuka honey, aloe vera gel) }\end{array}$ & $\begin{array}{c}\text { Sodium } \\
\text { alginate/methylcellulose } \\
\text { hydrogels }\end{array}$ & 3D bioprinting & $\begin{array}{l}\text { S. aureus and E. coli + human } \\
\text { dermal fibroblasts }\end{array}$ & [126] \\
\hline $\begin{array}{l}\text { Silvery wormwood oil } \\
\text { (Artemisia argyi) }\end{array}$ & $\begin{array}{l}\text { Sodium } \\
\text { alginate/polyvinyl alcohol } \\
\text { microcapsules/nanofibrous } \\
\text { membranes }\end{array}$ & $\begin{array}{l}\text { Emulsification-internal } \\
\text { gelation/electrospinning }\end{array}$ & Escherichia coli & {$[127]$} \\
\hline $\begin{array}{l}\text { Cabreuva essential oil } \\
\text { (Myrocarpus fastigiatus) }\end{array}$ & $\begin{array}{l}\text { Polyvinyl } \\
\text { alcohol/chitosan } \\
\text { nanofibers }\end{array}$ & Electrospinning & $\begin{array}{l}\text { Candida albicans, E. coli, } \\
\text { S. aureus, and } \\
\text { Staphylococcus epidermidis }\end{array}$ & {$[128]$} \\
\hline $\begin{array}{c}\text { Cardamom oil } \\
\text { (Elettaria Cardamomum) }\end{array}$ & Chitosan nanocomposites & $\begin{array}{c}\text { Ionic } \\
\text { gelation/utrasonication }\end{array}$ & $\begin{array}{l}\text { S. aureus, and E. coli + human } \\
\text { corneal epithelial cells and } \\
\text { human hepatocellular } \\
\text { carcinoma cells }\end{array}$ & {$[129]$} \\
\hline
\end{tabular}


Table 1. Cont.

\begin{tabular}{|c|c|c|c|c|}
\hline Essential Oils & Wound Dressing System & Method & Bioassay & References \\
\hline \multirow[b]{2}{*}{ Cinnamaldehyde } & Chitosan fibers & Centrifugal spinning & Staphylococcus aureus & {$[130]$} \\
\hline & $\begin{array}{l}\text { Chitosan/polyethylene } \\
\text { oxide }\end{array}$ & Electrospinning & $\begin{array}{c}\text { Escherichia coli and } \\
\text { Pseudomonas aeruginosa. }\end{array}$ & {$[131]$} \\
\hline $\begin{array}{l}\text { Clove and Sandalwood oils } \\
\text { (Syzygium aromaticum and } \\
\text { Santalum) }\end{array}$ & $\begin{array}{c}\text { Dextran/ } \\
\text { nanosoy/glycerol/ } \\
\text { chitosan nanocomposite } \\
\text { membranes }\end{array}$ & Nanoprecipitation/casting & S. aureus and E. coli & [132] \\
\hline $\begin{array}{l}\text { Eugenol oil (Clove oil- } \\
\text { Syzygium aromaticum) }\end{array}$ & $\begin{array}{l}\text { Polycaprolactone/polyvinyl } \\
\text { alcohol/chitosan fiber }\end{array}$ & Emulsion electrospinning & $\begin{array}{l}\text { Staphylococcus aureus and } \\
\text { Pseudomonas aeruginosa }\end{array}$ & [133] \\
\hline \multirow{2}{*}{ Thyme oil (Zataria multiflora) } & $\begin{array}{l}\text { Chitosan poly(vinyl } \\
\text { alcohol)/gelatin } \\
\text { nanofibers }\end{array}$ & Electrospinning & $\begin{array}{c}\text { Staphylococcus aureus, } \\
\text { Pseudomonas aeruginosa and } \\
\text { Candida albicans }\end{array}$ & {$[134]$} \\
\hline & $\begin{array}{l}\text { chitosan/poly(vinyl } \\
\text { alcohol)/gelatin. into poly } \\
\text { (vinyl alcohol) nanofibers }\end{array}$ & Electrospinning & $\begin{array}{c}\text { Staphylococcus aureus, } \\
\text { Pseudomonas aeruginosa and } \\
\text { Candida albicans + scaffolds on } \\
\text { mouse fibroblast cells }\end{array}$ & [134] \\
\hline $\begin{array}{l}\text { Terpinen-4-ol (from } \\
\text { Melaleuca alternifolia } \\
\quad \text { essential oil) }\end{array}$ & $\begin{array}{l}\text { Liposomes-incorporated } \\
\text { chitosan/polyethylene } \\
\text { oxide electrospun } \\
\text { nanofibrous film }\end{array}$ & $\begin{array}{l}\text { Thin-film hydration and } \\
\text { electrospinning }\end{array}$ & $\begin{array}{c}\text { Candida albicans, } \\
\text { Escherichia coli, } \\
\text { Staphylococcus aureus + mouse } \\
\text { fibroblast cells }\end{array}$ & [135] \\
\hline $\begin{array}{l}\text { Satureja mutica or } \\
\text { Oliveria decumbens essential oil }\end{array}$ & $\begin{array}{l}\text { Chitosan/polyvinyl } \\
\text { alcohol as core and } \\
\text { polyvinylpyrroli- } \\
\text { done/maltodextrin } \\
\text { as shell }\end{array}$ & Electrospinning & $\begin{array}{l}\text { E. coli, S. aureus, and } \\
\text { P. Aeruginosa and } \\
\text { antioxidant activity }\end{array}$ & {$[136]$} \\
\hline Zataria multiflora essential oil & $\begin{array}{l}\text { chitosan/poly(vinyl } \\
\text { alcohol)/gelatin }\end{array}$ & Electrospinning & $\begin{array}{c}\text { Staphylococcus aureus, } \\
\text { Pseudomonas aeruginosa, and } \\
\text { Candida albicans }\end{array}$ & {$[137]$} \\
\hline
\end{tabular}

Thymol (TH) and its isomer carvacrol (CA) are monoterpenoid phenols from the Origanum genus. They are found in thyme oil extracted from Thymus vulgaris, a plant from the Lamiaceae family and a native plant of Southern Europe ranging from the Western Mediterranean to Southern Italy [14]. Many studies have shown that carvacrol and thymol have anti-inflammatory, antioxidant, skin fibroblast-stimulating, and antibiotic effects in the wound-healing process [138-146]. In this regard, Hamedi et al. loaded a thyme oil nanoemulsion in chitosan alginate films (TM-PEC) at two different polymer ratios of polymers of 0.4 and $1 \mathrm{w} / \mathrm{v} \%$ through a solvent evaporation technique [103]. An invitro antibacterial test proved that the thyme-formulated films could limit the growth of Escherichia coli and Staphylococcus aureus. Viable cell counting demonstrated the antibacterial effect of nanoemulsion-films, and the release profile showed a controlled kinetic during the time $(150 \mathrm{~h})$ after an initial burst. Furthermore, the good value obtained by the tensile strength test confirmed these biomaterials suitable as wound dressings [103].

Oregano (Origanum vulgare) is a plant from the mint family native to Western and Southwestern Eurasia and the Mediterranean region. Turmeric (Curcuma longa) is in the ginger family and a native plant to the Indian subcontinent and southeast Asia. The essential oils of these plants have potential applications in wound healing because of their antimicrobial and antioxidant ability (Figure 3) [146]. In this respect, Sami et al. fabricated different types of dressings (ointment, hydrogel, and nanofiber) with $5 \%$ turmeric, $1 \%$ oregano, and $1 \%$ chitosan nanoparticles and compared their antibacterial, antioxidant, and cytotoxicity properties with those of commercial alginate silver dressing [147]. The antioxidant test showed that ethanolic turmeric extract had better antioxidant activity than oregano, chitosan nanoparticles, and alginate silver $(p$ value $<0.0001)$. Thus, the bioassay result showed that the ointment, hydrogel, and commercial alginate silver produced $100 \%$ inhibition against S. aureus and E. coli, and nanofibers produced 50\% inhibition [148]. In another study, Berechet et al. formulated thyme or oregano essential oils into the 
collagen nanofibers and evaluated the dressing system in an antimicrobial test [149]. The microbiological results showed that the nanofibers were active against $S$. aureus, E. coli, P. aeruginosa, and C. albicans [149].<smiles>O=C/C=C/c1ccccc1</smiles><smiles>Cc1ccc(C(C)C)c(O)c1</smiles><smiles>Cc1ccc(C(C)C)cc1O</smiles><smiles>CC(C)C1=CC=C(O)CC1</smiles><smiles>CC(C)C1=CCC(O)=CC1</smiles><smiles>CC(C)[C@]1(O)CC=C(O)CC1</smiles><smiles>CC1(C)O[C@]2(C)CC[C@H]1CC2</smiles>

Figure 3. (a) Cinnamaldehyde, (b) and (c) two main oregano oil ingredients thymol and carvacrol, (d), (e) and (f) three main tea tree oil compounds $\alpha$-terpinene, $\gamma$-terpinene, and terpinen-4-ol, and (g) 1,8-cineole one of the main ingredient of eucalyptus oil.

Cinnamaldehyde (CAL) or (2E)-3-Phenylprop-2-enal is found in cinnamon essential oil (55-76\%) isolated from cinnamon trees, camphor, and cassia. CAL is used in wound healing for antibacterial and antifungal activity and as an anti-inflammatory agent (Figure 3) [150]. Kenawy et al. incorporated CAL into gelatin/chitosan biopolymer membranes and investigated their microbiological activity [151]. The result showed that the developed CAL/gelatin/chitosan membranes inhibited the growth of three Gram-negative bacteria species (P. aeruginosa, Salmonella, and E. coli) and one Gram-positive bacteria species (S. aureus). Based on their results, they proposed that the bioactive, biodegradable, and nontoxic CAL/gelatin/chitosan membranes could be a promising candidate for wound dressing applications [151]. In another study, Liakos et al. demonstrated the antimicrobial activity of cinnamon, lemongrass, and peppermint essential oils encapsulated in cellulosebased fiber dressings. These formulated products inhibited the growth of Escherichia coli and showed good biocompatibility when tested on fibroblasts and keratinocytes as cell models (NIH3T3 and HaCaT cells) [152].

Another essential oil widely used in wound healing is tea tree oil (TTO), which is extracted from the leaves of $M$. alternifolia $[153,154]$. Three main compounds of TTO, terpinen4-ol, $\gamma$-terpinene, and $\alpha$-terpinene are shown in Figure 3 [155]. The presence of terpene hydrocarbons and tertiary alcohols results in TTO antimicrobial and anti-inflammatory activity and helps in the regeneration of collagen [156]. In one study, Flores et al. formulated a TTO nanocapsule (TTO-NC) and nanoemulsions (TTO-NE) into the hydrogels separately and compared both systems [102]. They investigated their influence on the treatment of inflammatory disorders and wound healing [102]. The result showed that both formulated hydrogels could promote the healing process, although the TTO-NC hydrogel could heal the wounds faster than TTO-NE by reducing inflammation [102]. Green tea extract (GT) is another tea tree product isolated from the leaf of Camellia sinensis. Sadri et al. formulated green tea extract in chitosan/polyethylene oxide nanofiber to investigate the wound-healing effect of GT [157]. The antibacterial assay on chitosan/PEO/GT nanofibers showed inhibition against Escherichia coli and Staphylococcus aureus. The in vivo study was 
conducted on rat, and the result showed that chitosan/PEO/GT nanofiber could accelerate the healing process, and the wound recovered completely after 16 days [157].

Eucalyptus oil with its main compound 1,8-cineole is extracted from Eucalyptus globulus, an evergreen tree with endemic wild growth in southeastern Australia (Figure 3) [158]. Sugumar et al. formulated a eucalyptus oil nanoemulsion for topical application to investigate the antibacterial and wound-healing potential against Staphylococcus aureus and Wistar rats, respectively [158]. The O/W nanoemulsions were prepared by ultrasonic method using the nonionic surfactant Tween 80 . They showed that the viability of Staphylococcus aureus was affected within 15 min of contact with the eucalyptus oil nanoemulsion, and bacterial membrane damage occurred. Animal studies showed a higher wound contraction rate compared to control and neomycin and confirmed that the formulation was not irritating [158]. In another study, Sugumar et al. impregnated eucalyptus oil nanoemulsion in chitosan film by casting method and performed the antibacterial test on formulated film. The in vitro bioassay on formulated films content $3 \%$ eucalyptus oil had activity against Staphylococcus aureus [159].

Lawsonia inermis Linn is extracted from the henna tree and can be used in the healing of chronic and burn wounds due to its antioxidant, analgesic, anti-inflammatory, antibacterial, and antifungal activities. Yousefi et al. prepared chitosan/polyethylene oxide (PEO) (90/10) nanofiber with Lawsonia inermis ( $2 \mathrm{wt} \%$ ) by electrospinning [160]. The enriched nanofiber showed antimicrobial activity against Escherichia coli and Staphylococcus aureus. The in vivo test was performed on the back of rats for 14 days (Figure 4). The results showed that Lawsonia inermis could promote the wound-healing process [160].

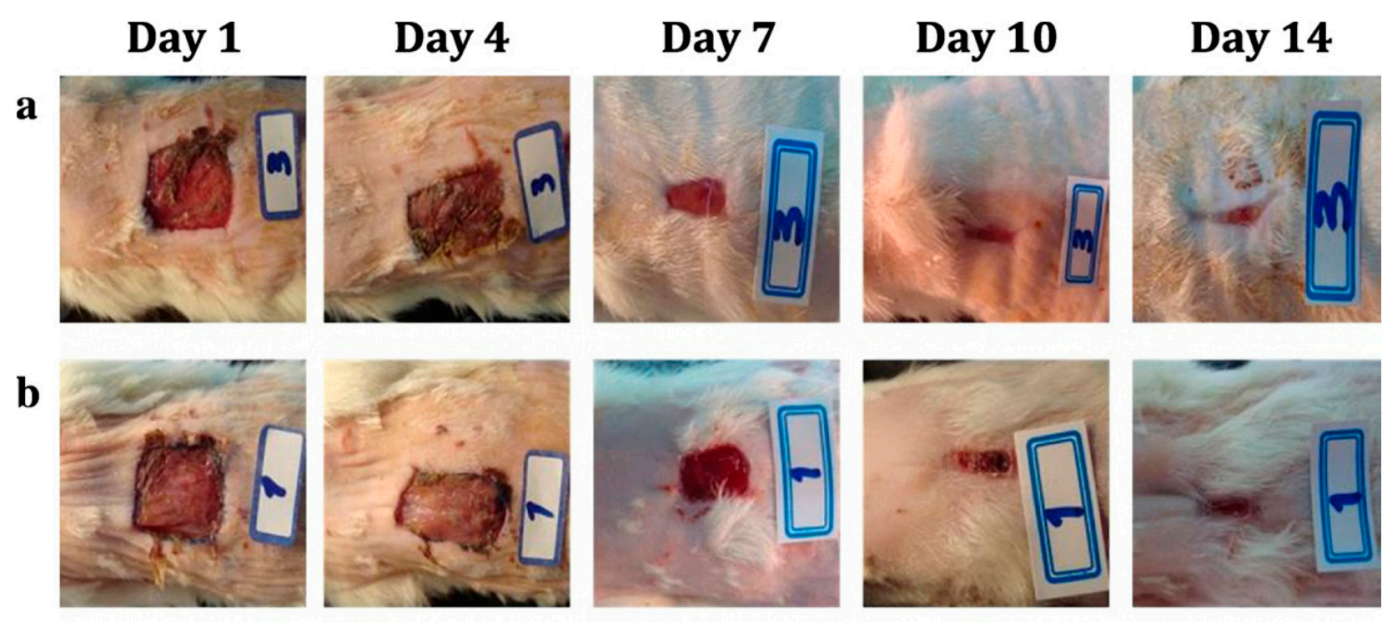

Figure 4. In vivo test on the back of the rats. (a) Blank chitosan/PEO nanofiber, (b) chitosan/PEO nanofiber containing $2 \mathrm{wt} \%$ L. inermis [160].

Lavender EO (LEO) is extracted from the flowers of Lavandula angustifolia and is known as an anxiety reducer, pain reliever, antioxidant, and anticancer agent [161,162]. Hajili et al. formulated lavender EO in Alginate (SA)/PEO nanofiber to evaluate LEO antibacterial and anti-inflammatory activity and its influence in recovering burn wounds [163]. The antibacterial results showed nanofiber inhibition against Staphylococcus aureus. The antiinflammatory activity was determined by in vivo test on the rat skin exposed to midrange ultraviolet radiation (UVB). The data suggested that the designed dressings affected the bacteria vitality. They were able to reduce the production of proinflammatory cytokines in human fibroblast cells by polymerase chain reaction (PCR) analysis and in mice exposed to UVB irradiation, evaluated by enzyme-linked immunosorbent assay (ELISA). This result proved that in the role of LEO in burn wound treatment by backing the cytokine levels to control value after $96 \mathrm{~h}$ without the appearance of erythema on their injured skin [163].

Lavender essential oil (LEO) is extracted from the flowers of Lavandula angustifolia and is known as an anti-anxiety, analgesic, antioxidant, and anticancer agent [161,162]. 
Hajili et al. formulated LEO in alginate/PEO nanofibers to investigate the antibacterial and anti-inflammatory activity of LEO and its effect on the healing of burn wounds [163]. The antibacterial results showed inhibition of nanofibers against Staphylococcus aureus. The anti-inflammatory activity was determined by an in vivo assay on rat skin exposed to medium ultraviolet radiation (UVB). The data suggested that the designed dressings affected the vitality of bacteria [163].

Clove oil extracted from Syzygium aromaticum exhibits antioxidant and anticancer activity due to its secondary metabolite eugenol. Alam et al. first analyzed the effect of clove oil in a wound excision rat model by oral administration. A clove oil nanoemulsion was obtained by spontaneous emulsification using triacetin as oil phase, Tween- 80 as surfactant, Labrasol as cosurfactant, and distilled water as aqueous phase. It was found that the leucine content was higher compared to the treatment with pure clove oil and the control. Moreover, the absence of inflammatory cells in nanoemulsion-treated rats in the histopathological experiments showed that the clove oil nanoemulsion was safe and nontoxic [164].

\section{Conclusions and Future Perspectives}

As a complicated process, wound healing requires several physiological activities. Therefore, the selection of suitable wound dressing systems is vital. As an alternative for conventional wound dressing, polysaccharide-based biopolymers such as chitosan and alginate are promising because of their biocompatibility, biodegradability, antimicrobial activity, and ability to accelerate wound healing. Thus, they are considered promising materials for wound dressing applications. Nanotechnology has increasingly revolutionized medical care, and its potential has also been investigated for the formulation of wound dressings. The application of secondary natural products in active wound dressings as antimicrobial and antioxidant additives is promising, providing fully biodegradable and sustainable biomaterials. However, there is a deep gap between laboratory scale research and clinical scale and even commercialization. To achieve this goal, the future trend in bioactive wound dressings should focus on overcoming the limitation of extracting natural products to improve their sustainability by using more environmentally friendly and costeffective approaches and carefully investigating clinically the problem of toxicity of natural products and lack of uptake by host cells.

Author Contributions: Conceptualization, A.M.; validation, A.M., P.C., A.D.S. and N.G.; investigation, I.D.L., and A.M.; writing—original draft preparation, I.D.L., P.P., A.M.; writing-review and editing, N.G., A.M., P.C., G.P. and A.D.S.; visualization, P.P., and I.D.L.; supervision N.G., A.D.S., and A.M. All authors have read and agreed to the published version of the manuscript.

Funding: The current work was partially funded by the Allianz Industrie Forschung (AiF) grant (Funding code: ZF4025045AJ9), as a part of the Central Innovation Program Initiative of the Federal Government of Germany. This research was also funded by the Italian Ministry of University and Research (PON 03 PE_00110_1/ptd1_000410 Titolo: Sviluppo di nanotecnologie Orientate alla Rigenerazone e Ricostruzione tissutale, Implantologia e Sensoristica in Odontoiatria/oculistica (SORRISO) (approval date 2 January 2019); POR Campania FESR 2014_2020 “Tecnologie abilitanti per la sintesi eco-sostenibile di nuovi materiali per la restaurativa dentale"- ABILTECH (approval date 29 October 2018). We would like to extend our sincere thanks to the project H2020-MSCA-RISE-Marie Sklodowska-Curie Actions (MSCA) Research and Innovation Staff Exchange (RISE) for funding this work, Project Acronym: VAHVISTUS-Project Number: 734759.

Institutional Review Board Statement: Not applicable.

Informed Consent Statement: Not applicable.

Data Availability Statement: Data sharing not applicable.

Conflicts of Interest: The authors declare no conflict of interest. 


\section{References}

1. Dreifke, M.B.; Jayasuriya, A.A.; Jayasuriya, A.C. Current wound healing procedures and potential care. Mater. Sci. Eng. C 2015, 48, 651-662. [CrossRef] [PubMed]

2. MacNeil, S. Progress and opportunities for tissue-engineered skin. Nature 2007, 445, 874. [CrossRef] [PubMed]

3. Bhardwaj, N.; Chouhan, D.; B Mandal, B. Tissue Engineered Skin and Wound Healing: Current Strategies and Future Directions. Curr. Pharm. Des. 2017, 23, 3455-3482. [CrossRef]

4. Kapoor, M.; Appleton, I. Wound healing: Abnormalities and future therapeutic targets. Curr. Anaesth. Crit. Care 2005, 16, 88-93. [CrossRef]

5. Moura, L.I.F.; Dias, A.M.A.; Carvalho, E.; de Sousa, H.C. Recent advances on the development of wound dressings for diabetic foot ulcer treatment-A review. Acta Biomater. 2013, 9, 7093-7114. [CrossRef]

6. Cañedo-dorantes, L.; Cañedo-ayala, M. Skin Acute Wound Healing: A Comprehensive Review. Int. J. Inflamm. 2019, $2019,3706315$. [CrossRef]

7. Sinno, H.; Prakash, S. Complements and the Wound Healing Cascade: An Updated Review. Plast. Surg. Int. 2013, 2013, 146764. [CrossRef]

8. Tsala, D.E.; Dawe, A.; Habtemariam, S. Natural wound healing and bioactive natural products. Phytopharmacology 2013, 4, 532-560.

9. Elnar, T.V.; Ailey, T.B. The Wound Healing Process: An Overview of the Cellular and Molecular Mechanisms. J. Int. Med Res. 2009, 37, 1528-1542. [CrossRef] [PubMed]

10. Stephens, P.; Thomas, D.W. The cellular proliferative phase of the wound repair process. J. Wound Care 2013, 11. [CrossRef] [PubMed]

11. Gurtner, G.C.; Werner, S.; Barrandon, Y.; Longaker, M.T. Wound repair and regeneration. Nature 2008, 453, 314. [CrossRef] [PubMed]

12. Bielefeld, K.A.; Amini-Nik, S.; Alman, B.A. Cutaneous wound healing: Recruiting developmental pathways for regeneration. Cell. Mol. Life Sci. 2013, 70, 2059-2081. [CrossRef]

13. Das, S.; Baker, A.B. Biomaterials and Nanotherapeutics for Enhancing Skin Wound Healing. Front. Bioeng. Biotechnol. 2016, 4 , 82. Available online: https://www.frontiersin.org/article/10.3389/fbioe.2016.00082 (accessed on 31 October 2016). [CrossRef] [PubMed]

14. Moeini, A.; Pedram, P.; Makvandi, P.; Malinconico, M.; d'Ayala, G.G. Wound healing and Antimicrobial effect of active Secondary Metabolites in Chitosan-based Wound dressings: A review. Carbohydr. Polym. 2020, 115839. [CrossRef]

15. Suarato, G.; Bertorelli, R.; Athanassiou, A. Borrowing From Nature: Biopolymers and Biocomposites as Smart Wound Care Materials. Front. Bioeng. Biotechnol. 2018, 6, 137. [CrossRef] [PubMed]

16. Sikka, M.P.; Midha, V.K. The Role of Biopolymers and Biodegradable Polymeric Dressings in Managing Chronic Wounds, 2nd ed.; Elsevier Ltd.: Amsterdam, The Netherlands; Woodhead Publishing: Sawston, UK, 2019. [CrossRef]

17. Sood, A.; Granick, M.S.; Tomaselli, N.L. Wound Dressings and Comparative Effectiveness Data. Adv. Wound Care 2014, 3, 511-529. [CrossRef]

18. Naskar, A.; Kim, K.S. Recent advances in nanomaterial-based wound-healing therapeutics. Pharmaceutics 2020, 12, 499. [CrossRef]

19. Sahana, T.G.; Rekha, P.D. Biopolymers: Applications in wound healing and skin tissue engineering. Mol. Biol. Rep. 2018, 45, 2857-2867. [CrossRef]

20. Tran, P.L.; Hamood, A.N.; de Souza, A.; Schultz, G.; Liesenfeld, B.; Mehta, D.; Reid, T.W. A study on the ability of quaternary ammonium groups attached to a polyurethane foam wound dressing to inhibit bacterial attachment and biofilm formation. Wound Repair Regen. 2015, 23, 74-81. [CrossRef]

21. Park, J.-H.; Choi, S.-H.; Park, S.-J.; Lee, Y.J.; Park, J.H.; Song, P.H.; Cho, C.-M.; Ku, S.-K.; Song, C.-H. Promoting Wound Healing Using Low Molecular Weight Fucoidan in a Full-Thickness Dermal Excision Rat Model. Mar. Drugs 2017, 15, 112. [CrossRef]

22. Gokarneshan, N. Review article-role of Chitosan in Wound Healing-A Review of the Recent Advances. Glob. J. Addic. Rehab. Med. 2017, 4, 555-636. [CrossRef]

23. Prosdocimi, M.; Bevilacqua, C. Exogenous hyaluronic acid and wound healing: An updated vision. Panminerva Med. 2012, 54, 129-135. [PubMed]

24. Straccia, M.C.; D’Ayala, G.G.; Romano, I.; Oliva, A.; Laurienzo, P. Alginate hydrogels coated with chitosan for wound dressing Mar. Drugs 2015, 13, 2890-2908. [CrossRef]

25. Helary, C.; Abed, A.; Mosser, G.; Louedec, L.; Letourneur, D.; Coradin, T.; Giraud-Guille, M.M.; Meddahi-Pellé, A. Evaluation of dense collagen matrices as medicated wound dressing for the treatment of cutaneous chronic wounds. Biomater. Sci. 2015, 3, 373-382. [CrossRef]

26. Zare-Gachi, M.; Daemi, H.; Mohammadi, J.; Baei, P.; Bazgir, F.; Hosseini-Salekdeh, S.; Baharvand, H. Improving anti-hemolytic, antibacterial and wound healing properties of alginate fibrous wound dressings by exchanging counter-cation for infected full-thickness skin wounds. Mater. Sci. Eng. C 2020, 107, 110321. [CrossRef]

27. Pacheco, M.S.; Kano, G.E.; Paulo, L.d.; Lopes, P.S.; de Moraes, M.A. Silk fibroin/chitosan/alginate multilayer membranes as a system for controlled drug release in wound healing. Int. J. Biol. Macromol. 2020, 152, 803-811. [CrossRef]

28. Li, Y.; Chi, Y.-Q.; Yu, C.-H.; Xie, Y.; Xia, M.-Y.; Zhang, C.-L.; Han, X.; Peng, Q. Drug-free and non-crosslinked chitosan scaffolds with efficient antibacterial activity against both Gram-negative and Gram-positive bacteria. Carbohydr. Polym. 2020, $241,116386$. [CrossRef] [PubMed] 
29. Hardy, A.; Seguin, C.; Brion, A.; Lavalle, P.; Schaaf, P.; Fournel, S.; Bourel-Bonnet, L.; Frisch, B.; de Giorgi, M. $\beta$-CyclodextrinFunctionalized Chitosan/Alginate Compact Polyelectrolyte Complexes (CoPECs) as Functional Biomaterials with AntiInflammatory Properties. ACS Appl. Mater. Interfaces 2018, 10, 29347-29356. [CrossRef]

30. Kim, S. Competitive Biological Activities of Chitosan and Its Derivatives: Antimicrobial, Antioxidant, Anticancer, and AntiInflammatory Activities. Int. J. Polym. Sci. 2018, 2018, 1-13. [CrossRef]

31. Rajendran, N.K.; Kumar, S.S.D.; Houreld, N.N.; Abrahamse, H. A review on nanoparticle based treatment for wound healing. J. Drug Deliv. Sci. Technol. 2018, 44, 421-430. [CrossRef]

32. Chou, S.F.; Gunaseelan, S.; Kiellani, M.H.H.; Thottempudi, V.V.K.; Neuenschwander, P.; Nie, H. A review of injectable and implantable biomaterials for treatment and repair of soft tissues in wound healing. J. Nanotechnol. 2017, 2017, 6341710. [CrossRef]

33. Moeini, A.; Masi, M.; Zonno, M.C.; Boari, A.; Cimmino, A.; Tarallo, O.; Vurro, M.; Evidente, A. Encapsulation of inuloxin A, a plant germacrane sesquiterpene with potential herbicidal activity, in $\beta$-cyclodextrins. Org. Biomol. Chem. 2019, 17, $2508-2515$. [CrossRef]

34. Johnson, J.L.; Raghavan, V.; Cimmino, A.; Moeini, A.; Petrovic, A.G.; Santoro, E.; Superchi, S.; Berova, N.; Evidente, A.; Polavarapu, P.L. Absolute configurations of chiral molecules with multiple stereogenic centers without prior knowledge of the relative configurations: A case study of inuloxin C. Chirality 2018, 30, 1206-1214. [CrossRef] [PubMed]

35. Amrati, F.E.Z.; Bourhia, M.; Slighoua, M.; Ibnemoussa, S.; Bari, A.; Ullah, R.; Amaghnouje, A.; di Cristo, F.; el Mzibri, M.; Calarco, A.; et al. Phytochemical Study on Antioxidant and Antiproliferative Activities of Moroccan Caralluma europaea Extract and Its Bioactive Compound Classes. Evid.-Based Complement. Altern. Med. 2020, 2020, 8409718. [CrossRef]

36. Bahramsoltani, R.; Farzaei, M.H.; Rahimi, R. Medicinal plants and their natural components as future drugs for the treatment of burn wounds: An integrative review. Arch. Dermatol. Res. 2014, 306, 601-617. [CrossRef]

37. Kusumawati, I.; Indrayanto, G. Chapter 15-Natural Antioxidants in Cosmetics. In Studies in Natural Products Chemistry; Atta-ur, R., Ed.; Elsevier: Amsterdam, The Netherlands, 2013; pp. 485-505. [CrossRef]

38. Singh, G.; Kapoor, I.P.S.; Pandey, S.K.; Singh, U.K.; Singh, R.K. Studies on essential oils: Part 10; Antibacterial activity of volatile oils of some spices. Phyther. Res. 2002, 16, 680-682. [CrossRef] [PubMed]

39. Houghton, P.J.; Hylands, P.J.; Mensah, A.Y.; Hensel, A.; Deters, A.M. In vitro tests and ethnopharmacological investigations: Wound healing as an example. J. Ethnopharmacol. 2005, 100, 100-107. [CrossRef] [PubMed]

40. Minagawa, T.; Okamura, Y.; Shigemasa, Y.; Minami, S.; Okamoto, Y. Effects of molecular weight and deacetylation degree of chitin/chitosan on wound healing. Carbohydr. Polym. 2007, 67, 640-644. [CrossRef]

41. Senni, K.; Pereira, J.; Gueniche, F.; Delbarre-Ladrat, C.; Sinquin, C.; Ratiskol, J.; Godeau, G.; Fischer, A.-M.; Helley, D.; ColliecJouault, S. Marine Polysaccharides: A Source of Bioactive Molecules for Cell Therapy and Tissue Engineering. Mar. Drugs 2011, 9, 1664-1681. [CrossRef]

42. Amaghnouje, A.; Mechchate, H.; Es-Safi, I.; Alotaibi, A.A.; Noman, O.M.; Nasr, F.A.; Al-Zharani, M.; Cerruti, P.; Calarco, A.; el Fatemi, H.; et al. Anxiolytic, antidepressant-like proprieties and impact on the memory of the hydro-ethanolic extract of origanum majorana L. On mice. Appl. Sci. 2020, 10, 8420. [CrossRef]

43. Amaghnouje, A.; Mechchate, H.; Es-safi, I.; Boukhira, S.; Aliqahtani, A.S.; Noman, O.M.; Nasr, F.A.; Conte, R.; Calarco, A.; Bousta, D. Subacute Assessment of the Toxicity and Antidepressant-Like Effects of Origanum Majorana L. Polyphenols in Swiss Albino Mice. Molecules 2020, 25, 5653. [CrossRef] [PubMed]

44. Masi, M.; Moeini, S.A.; Boari, A.; Cimmino, A.; Vurro, M.; Evidente, A. Development of a rapid and sensitive HPLC method for the identification and quantification of cavoxin and cavoxone in Phoma cava culture filtrates. Nat. Prod. Res. 2017, 6419, 1-5. [CrossRef] [PubMed]

45. Marturano, V.; Bizzarro, V.; Ambrogi, V.; Cutignano, A.; Tommonaro, G.; Abbamondi, G.R.; Giamberini, M.; Tylkowski, B.; Carfagna, C.; Cerruti, P. Light-responsive nanocapsule-coated polymer films for antimicrobial active packaging. Polymers 2019, 11, 68. [CrossRef]

46. Marturano, V.; Marcille, H.; Cerruti, P.; Bandeira, N.A.G.; Giamberini, M.; Trojanowska, A.; Tylkowski, B.; Carfagna, C.; Ausanio, G.; Ambrogi, V. Visible-Light Responsive Nanocapsules for Wavelength-Selective Release of Natural Active Agents. ACS Appl. Nano Mater. 2019, 2, 4499-4506. [CrossRef]

47. Moeini, A.; van Reenen, A.; van Otterlo, W.; Cimmino, A.; Masi, M.; Lavermicocca, P.; Valerio, F.; Immirzi, B.; Santagata, G.; Malinconico, M.; et al. $\alpha$-costic acid, a plant sesquiterpenoid from Dittrichia viscosa, as modifier of Poly (lactic acid) properties: A novel exploitation of the autochthone biomass metabolite for a wholly biodegradable system. Ind. Crops Prod. 2020, $146,112134$. [CrossRef]

48. Moeini, A.; Mallardo, S.; Cimmino, A.; Poggetto, G.D.; Masi, M.; di Biase, M.; van Reenen, A.; Lavermicocca, P.; Valerio, F.; Evidente, A.; et al. Thermoplastic starch and bioactive chitosan sub-microparticle biocomposites: Antifungal and chemicophysical properties of the films. Carbohydr. Polym. 2020, 230, 115627. [CrossRef]

49. Moeini, A.; Cimmino, A.; Masi, M.; Evidente, A.; van Reenen, A. The incorporation and release of ungeremine, an antifungal Amaryllidaceae alkaloid, in poly(lactic acid)/poly(ethylene glycol) nanofibers. J. Appl. Polym. Sci. 2020, 137, 49098. [CrossRef]

50. Moeini, A.; Cimmino, A.; Poggetto, G.D.; di Biase, M.; Evidente, A.; Masi, M.; Lavermicocca, P.; Valerio, F.; Leone, A.; Santagata, G.; et al. Effect of $\mathrm{pH}$ and TPP concentration on chemico-physical properties, release kinetics and antifungal activity of ChitosanTPP-Ungeremine microbeads. Carbohydr. Polym. 2018, 195, 631-641. [CrossRef] 
51. Valerio, F.; Masi, M.; Cimmino, A.; Moeini, S.A.; Lavermicocca, P.; Evidente, A. Antimould microbial and plant metabolites with potential use in intelligent food packaging. Nat. Prod. Res. 2017, 6419, 1-6. [CrossRef]

52. Kumar, L.; Brice, J.; Toberer, L.; Klein-Seetharaman, J.; Knauss, D.; Sarkar, S.K. Antimicrobial biopolymer formation from sodium alginate and algae extract using aminoglycosides. PLOS ONE 2019, 14, e0214411. [CrossRef]

53. Homaeigohar, S.; Boccaccini, A.R. Antibacterial biohybrid nanofibers for wound dressings. Acta Biomater. 2020, 107, 25-49. [CrossRef] [PubMed]

54. Farokhi, M.; Mottaghitalab, F.; Fatahi, Y.; Khademhosseini, A.; Kaplan, D.L. Overview of Silk Fibroin Use in Wound Dressings. Trends Biotechnol. 2018, 36, 907-922. [CrossRef]

55. Boateng, J.; Catanzano, O. Advanced Therapeutic Dressings for Effective Wound Healing-A Review. J. Pharm. Sci. 2015, 104, 3653-3680. [CrossRef]

56. Harrison, I.P.; Spada, F. Hydrogels for Atopic Dermatitis and Wound Management: A Superior Drug Delivery Vehicle. Pharmaceutics 2018, 10, 71. [CrossRef]

57. Chen, H.; Cheng, R.; Zhao, X.; Zhang, Y.; Tam, A.; Yan, Y.; Shen, H.; Zhang, Y.S.; Qi, J.; Feng, Y.; et al. An injectable self-healing coordinative hydrogel with antibacterial and angiogenic properties for diabetic skin wound repair. NPG Asia Mater. 2019, 11, 3. [CrossRef]

58. Xue, Z.; Wang, S.; Lin, L.; Chen, L.; Liu, M.; Feng, L.; Jiang, L. A Novel Superhydrophilic and Underwater Superoleophobic Hydrogel-Coated Mesh for Oil/Water Separation. Adv. Mater. 2011, 23, 4270-4273. [CrossRef]

59. Namazi, H.; Rakhshaei, R.; Hamishehkar, H.; Kafil, H.S. Antibiotic loaded carboxymethylcellulose/MCM-41 nanocomposite hydrogel films as potential wound dressing. Int. J. Biol. Macromol. 2016, 85, 327-334. [CrossRef]

60. Zhang, D.; Zhou, W.; Wei, B.; Wang, X.; Tang, R.; Nie, J.; Wang, J. Carboxyl-modified poly(vinyl alcohol)-crosslinked chitosan hydrogel films for potential wound dressing. Carbohydr. Polym. 2015, 125, 189-199. [CrossRef] [PubMed]

61. Monjezi, J.; Jamaledin, R.; Ghaemy, M.; Moeini, A.; Makvandi, P. A Performance Comparison of Graft Copolymer Hydrogels Based on Functionalized-Tragacanth Gum/Polyacrylic Acid and Polyacrylamide as Antibacterial and Antifungal Drug Release Vehicles. Am. J. Nanotechnol. Nanomed. Res. 2018, 1, 010-015.

62. Singh, R.; Singh, D. Radiation synthesis of PVP/alginate hydrogel containing nanosilver as wound dressing. J. Mater. Sci. Mater. Med. 2012, 23, 2649-2658. [CrossRef]

63. Kamoun, E.A.; Kenawy, E.-R.S.; Chen, X. A review on polymeric hydrogel membranes for wound dressing applications: PVA-based hydrogel dressings. J. Adv. Res. 2017, 8, 217-233. [CrossRef] [PubMed]

64. Makvandi, P.; Gu, J.t.; Zare, E.N.; Ashtari, K.; Moeini, A.; Tay, F.R.; Niu, L. Polymeric and inorganic nanoscopical antimicrobial fillers in dentistry. Acta Biomater. 2020, 101, 69-101. [CrossRef]

65. Stashak, T.S.; Farstvedt, E.; Othic, A. Update on wound dressings: Indications and best use. Clin. Tech. Equine Pract. 2004, 3, 148-163. [CrossRef]

66. Jayakumar, R.; Prabaharan, M.; Kumar, P.T.S.; Nair, S.V.; Tamura, H. Biomaterials based on chitin and chitosan in wound dressing applications. Biotechnol. Adv. 2011, 29, 322-337. [CrossRef]

67. Lin, W.-C.; Lien, C.-C.; Yeh, H.-J.; Yu, C.-M.; Hsu, S. Bacterial cellulose and bacterial cellulose-chitosan membranes for wound dressing applications. Carbohydr. Polym. 2013, 94, 603-611. [CrossRef]

68. Sezer, A.D.; Cevher, E. Biopolymers as Wound Healing Materials: Challenges and New Strategies. In Biomaterials Applications for Nanomedicine; IntechOpen: London, UK, 2011; pp. 383-414. [CrossRef]

69. Bianchera, A.; Catanzano, O.; Boateng, J.; Elviri, L. The Place of Biomaterials in Wound Healing. Ther. Dress. Wound Heal. Appl. 2020, 337-366. [CrossRef]

70. Nesic, A.; Moeini, A.; Santagata, G. Marine biopolymers: Alginate and chitosan. In Sustainability of Polymeric Materials; Marturano, V., Ambrogi, V., Eds.; De Gruyter: Berlin, Germany, 2020; p. 73. [CrossRef]

71. Huang, S.; Fu, X. Naturally derived materials-based cell and drug delivery systems in skin regeneration. J. Control. Release 2010, 142, 149-159. [CrossRef]

72. Hakkarainen, T.; Koivuniemi, R.; Kosonen, M.; Escobedo-Lucea, C.; Sanz-Garcia, A.; Vuola, J.; Valtonen, J.; Tammela, P.; Mäkitie, A.; Luukko, K.; et al. Nanofibrillar cellulose wound dressing in skin graft donor site treatment. J. Control. Release 2016, 244, $292-301$. [CrossRef] [PubMed]

73. Vijayakumar, V.; Samal, S.K.; Mohanty, S.; Nayak, S.K. Recent advancements in biopolymer and metal nanoparticle-based materials in diabetic wound healing management. Int. J. Biol. Macromol. 2019, 122, 137-148. [CrossRef]

74. Tayeb, A.H.; Amini, E.; Ghasemi, S.; Tajvidi, M. Cellulose nanomaterials-binding properties and applications: A review. Molecules 2018, 23, 2684. [CrossRef] [PubMed]

75. Yadav, T.C.; Srivastava, A.K.; Raghuwanshi, N.; Kumar, N.; Prasad, R.; Pruthi, V. Wound Healing Potential of Natural Polymer: Chitosan "A Wonder Molecule". Integr. Green Chem. Sustain. Eng. 2019, 527-579. [CrossRef]

76. Mohan, S.; Oluwafemi, O.S.; Kalarikkal, N.; Thomas, S.; Songca, S.P. Biopolymers-Application in Nanoscience and Nanotechnology. Recent Adv. Biopolym. 2016, 1, 47-66. [CrossRef]

77. Weller, C.D.; Team, V.; Sussman, G. First-Line Interactive Wound Dressing Update: A Comprehensive Review of the Evidence. Front. Pharmacol. 2020, 11, 155. [CrossRef]

78. Hamdan, S.; Pastar, I.; Drakulich, S.; Dikici, E.; Tomic-Canic, M.; Deo, S.; Daunert, S. Nanotechnology-Driven Therapeutic Interventions in Wound Healing: Potential Uses and Applications. ACS Cent. Sci. 2017, 3, 163-175. [CrossRef] 
79. Zarrintaj, P.; Moghaddam, A.S.; Manouchehri, S.; Atoufi, Z.; Amiri, A.; Amirkhani, M.A.; Nilforoushzadeh, M.A.; Saeb, M.R.; Hamblin, M.R.; Mozafari, M. Can regenerative medicine and nanotechnology combine to heal wounds? the search for the ideal wound dressing. Nanomedicine 2017, 12, 2403-2422. [CrossRef] [PubMed]

80. Berthet, M.; Gauthier, Y.; Lacroix, C.; Verrier, B.; Monge, C. Nanoparticle-Based Dressing: The Future of Wound Treatment? Trends Biotechnol. 2017, 35, 770-784. [CrossRef]

81. Bhattacharya, D.; Ghosh, B.; Mukhopadhyay, M. Development of nanotechnology for advancement and application in wound healing: A review. IET Nanobiotechnol. 2019, 13, 778-785. [CrossRef]

82. Du, J.; Wong, K.K.Y. Nanomaterials for Wound Healing: Scope and Advances; Elsevier Inc.: Amsterdam, The Netherlands, 2019. [CrossRef]

83. Singh, Y.; Meher, J.G.; Raval, K.; Khan, F.A.; Chaurasia, M.; Jain, N.K.; Chourasia, M.K. Nanoemulsion: Concepts, development and applications in drug delivery. J. Control. Release 2017, 252, 28-49. [CrossRef]

84. Niska, K.; Zielinska, E.; Radomski, M.W.; Inkielewicz-Stepniak, I. Metal nanoparticles in dermatology and cosmetology: Interactions with human skin cells. Chem. Biol. Interact. 2018, 295, 38-51. [CrossRef]

85. Ouyang, S.; Hu, X.; Zhou, Q.; Li, X.; Miao, X.; Zhou, R. Nanocolloids in Natural Water: Isolation, Characterization, and Toxicity. Environ. Sci. Technol. 2018, 52, 4850-4860. [CrossRef]

86. Korrapati, P.S.; Karthikeyan, K.; Satish, A.; Krishnaswamy, V.R.; Venugopal, J.R.; Ramakrishna, S. Recent advancements in nanotechnological strategies in selection, design and delivery of biomolecules for skin regeneration. Mater. Sci. Eng. C 2016, 67, 747-765. [CrossRef]

87. Liechty, W.B.; Kryscio, D.R.; Slaughter, B.V.; Peppas, N.A. Polymers for drug delivery systems. Annu. Rev. Chem. Biomol. Eng. 2010, 1, 149-173. [CrossRef]

88. Zhang, P.; He, L.; Zhang, J.; Mei, X.; Zhang, Y.; Tian, H.; Chen, Z. Preparation of novel berberine nano-colloids for improving wound healing of diabetic rats by acting Sirt1/NF-kB pathway. Colloids Surf. B Biointerfaces 2020, 187, 110647. [CrossRef] [PubMed]

89. Sen, C.K. Wound healing essentials: Let there be oxygen. Wound Repair Regen. 2009, 17, 1-18. [CrossRef]

90. Ashter, S.A. Thermoforming of Single and Multilayer Laminates: Plastic Films Technologies, Testing, and Applications, Thermoforming of Single and Multilayer Laminates: Plastic Films Technologies, Testing and Applications; William Andrew Publishing: Norwich, NY, USA, 2014; pp. 1-326.

91. Chakrabarti, S.; Chattopadhyay, P.; Islam, J.; Ray, S.; Raju, P.S.; Mazumder, B. Aspects of Nanomaterials in Wound Healing. Curr. Drug Deliv. 2019, 16, 26-41. [CrossRef]

92. Lei, J.; Sun, L.; Li, P.; Zhu, C.; Lin, Z. The Wound Dressings and Their Applications in Wound Healing and Management. Heal. Sci. J. 2019, 13, 1-8. Available online: http:/ /www.imedpub.com/ (accessed on 19 August 2019).

93. Bilia, A.R.; Guccione, C.; Isacchi, B.; Righeschi, C.; Firenzuoli, F.; Bergonzi, M.C. Essential oils loaded in nanosystems: A developing strategy for a successful therapeutic approach. Evid. Based. Complement. Alternat. Med. 2014, 2014, 651593. [CrossRef] [PubMed]

94. Echeverría, J.; de Albuquerque, R.D.D.G. Nanoemulsions of Essential Oils: New Tool for Control of Vector-Borne Diseases and In Vitro Effects on Some Parasitic Agents. Medicines 2019, 6, 42. [CrossRef] [PubMed]

95. Shakeel, F.; Faisal, M.S. Nanoemulsion: A promising tool for solubility and dissolution enhancement of celecoxib. Pharm. Dev. Technol. 2010, 15, 53-56. [CrossRef] [PubMed]

96. Azmi, N.A.; Elgharbawy, A.A.M.; Motlagh, S.R.; Samsudin, N.; Salleh, H.M. Nanoemulsions: Factory for food, pharmaceutical and cosmetics. Processes 2019, 7, 617. [CrossRef]

97. Gupta, A.; Eral, H.B.; Hatton, T.A.; Doyle, P.S. Nanoemulsions: Formation, properties and applications. Soft Matter. 2016, 12, 2826-2841. [CrossRef] [PubMed]

98. Simonazzi, A.; Cid, A.G.; Villegas, M.; Romero, A.I.; Palma, S.D.; Bermúdez, J.M. Chapter 3-Nanotechnology Applications in Drug Controlled Release. In Drug Targeting and Stimuli Sensitive Drug Delivery Systems; Grumezescu, A.M., Ed.; William Andrew Publishing: Norwich, NY, USA, 2018; pp. 81-116. [CrossRef]

99. Solans, C.; Izquierdo, P.; Nolla, J.; Azemar, N.; Garcia-Celma, M.J. Nano-emulsions. Curr. Opin. Colloid Interface Sci. 2005, 10, 102-110. [CrossRef]

100. Sayed, S. Essential Oil Nanoformulations as a Novel Method for Insect Pest Control in Horticulture. In Horticultural Crops; IntechOpen: London, UK, 2019. [CrossRef]

101. Abreu, F.S.; Costa, E.F.; Cardial, M.L.; André, W.P.P. Polymeric nanoemulsions enriched with Eucalyptus citriodora essential oil. Polímeros 2020, 30. [CrossRef]

102. Flores, F.; Lima, J.; Silva, C.; Benvegnú, D.; Ferreira, J.; Bürger, M.; Beck, R.; Rolim, C.; Rocha, M.; Veiga, M.; et al. Hydrogels Containing Nanocapsules and Nanoemulsions of Tea Tree Oil Provide Antiedematogenic Effect and Improved Skin Wound Healing. J. Nanosci. Nanotechnol. 2015, 15, 800-809. [CrossRef]

103. Hamedi, H.; Moradi, S.; Tonelli, A.E.; Hudson, S.M. Preparation and Characterization of Chitosan-Alginate Polyelectrolyte Complexes Loaded with Antibacterial Thyme Oil Nanoemulsions. Appl. Sci. 2019, 9, 3933. [CrossRef]

104. Wang, F.; Hu, S.; Jia, Q.; Zhang, L. Advances in Electrospinning of Natural Biomaterials for Wound Dressing. J. Nanomater. 2020, 2020, 8719859. [CrossRef] 
105. Bombin, A.D.J.; Dunne, N.J.; McCarthy, H.O. Electrospinning of natural polymers for the production of nanofibres for wound healing applications. Mater. Sci. Eng. C 2020, 114, 110994. [CrossRef]

106. Memic, A.; Abudula, T.; Mohammed, H.S.; Navare, K.J.; Colombani, T.; Bencherif, S.A. Latest Progress in Electrospun Nanofibers for Wound Healing Applications. ACS Appl. Bio Mater. 2019, 2, 952-969. [CrossRef]

107. Mele, E. Electrospinning of Essential Oils. Polymers 2020, 12, 908. [CrossRef]

108. Cai, H.; Li, G. Efficacy of alginate-and chitosan-based scaffolds on the healing of diabetic skin wounds in animal experimental models and cell studies: A systematic review. Wound Repair Regen. 2020, 28, 751-771. [CrossRef]

109. Qin, X. Coaxial electrospinning of nanofibers. In Electrospun Nanofibers; Woodhead Publishing: Sawston, UK, 2017 ; pp. 41-71. [CrossRef]

110. Zhu, L.; Liu, X.; Du, L.; Jin, Y. Preparation of asiaticoside-loaded coaxially electrospinning nanofibers and their effect on deep partial-thickness burn injury. Biomed. Pharmacother. 2016, 83, 33-40. [CrossRef] [PubMed]

111. Pawar, H.V.; Tetteh, J.; Boateng, J.S. Preparation, optimisation and characterisation of novel wound healing film dressings loaded with streptomycin and diclofenac. Colloids Surf. B Biointerfaces 2013, 102, 102-110. [CrossRef] [PubMed]

112. Sabitha, M.; Rajiv, S. Preparation and characterization of ampicillin-incorporated electrospun polyurethane scaffolds for wound healing and infection control. Polym. Eng. Sci. 2015, 55, 541-548. [CrossRef]

113. Lan, Y.; Li, W.; Guo, R.; Zhang, Y.; Xue, W.; Zhang, Y. Preparation and characterisation of vancomycin-impregnated gelatin microspheres/silk fibroin scaffold. J. Biomater. Sci. Polym. Ed. 2014, 25, 75-87. [CrossRef]

114. Pásztor, N.; Rédai, E.; Szabó, Z.-I.; Sipos, E. Preparation and Characterization of Levofloxacin-Loaded Nanofibers as Potential Wound Dressings. Acta Med. Marisiensis 2017, 63, 66-69. [CrossRef]

115. Mohseni, M.; Shamloo, A.; Aghababaei, Z.; Vossoughi, M.; Moravvej, H. Antimicrobial Wound Dressing Containing Silver Sulfadiazine With High Biocompatibility: In Vitro Study. Artif. Organs. 2016, 40, 765-773. [CrossRef] [PubMed]

116. Adhirajan, N.; Shanmugasundaram, N.; Shanmuganathan, S.; Babu, M. Collagen-based wound dressing for doxycycline delivery: In-vivo evaluation in an infected excisional wound model in rats. J. Pharm. Pharmacol. 2009, 61, 1617-1623. [CrossRef]

117. Shao, W.; Liu, H.; Wang, S.; Wu, J.; Huang, M.; Min, H.; Liu, X. Controlled release and antibacterial activity of tetracycline hydrochloride-loaded bacterial cellulose composite membranes. Carbohydr. Polym. 2016, 145, 114-120. [CrossRef]

118. Schultz, G.S.; Sibbald, R.G.; Falanga, V.; Ayello, E.A.; Dowsett, C.; Harding, K.; Romanelli, M.; Stacey, M.C.; Teot, L.; Vanscheidt, W. Wound bed preparation: A systematic approach to wound management. Wound Repair Regen. 2003, 11, S1-S28. [CrossRef]

119. Zhang, Q.; Fong, C.C.; Yu, W.K.; Chen, Y.; Wei, F.; Koon, C.M.; Lau, K.M.; Leung, P.C.; Lau, C.B.S.; Fung, K.P.; et al. Herbal formula Astragali Radix and Rehmanniae Radix exerted wound healing effect on human skin fibroblast cell line Hs27 via the activation of transformation growth factor (TGF- $\beta$ ) pathway and promoting extracellular matrix (ECM) deposition. Phytomedicine 2012, 20, 9-16. [CrossRef] [PubMed]

120. Luessen, H.; de Leeuw, B.J.; Langemeÿer, M.W.E.; Boer, A.; Verhoef, J.C.; Junginger, H.E. Mucoadhesive Polymers in Peroral Peptide Drug Delivery. VI. Carbomer and Chitosan Improve the Intestinal Absorption of the Peptide Drug Buserelin In Vivo Pharm. Res. 1996, 13, 1668-1672. [CrossRef] [PubMed]

121. Liu, R.; Zhang, L.; Lan, X.; Li, L.; Zhang, T.-T.; Sun, J.-H.; Du, G.-H. Protection by borneol on cortical neurons against oxygenglucose deprivation/reperfusion: Involvement of anti-oxidation and anti-inflammation through nuclear transcription factor kappaB signaling pathway. Neuroscience 2011, 176, 408-419. [CrossRef] [PubMed]

122. Blass, S.C.; Goost, H.; Tolba, R.H.; Stoffel-Wagner, B.; Kabir, K.; Burger, C.; Stehle, P.; Ellinger, S. Time to wound closure in trauma patients with disorders in wound healing is shortened by supplements containing antioxidant micronutrients and glutamine: A PRCT. Clin. Nutr. 2012, 31, 469-475. [CrossRef]

123. Thakur, R.; Jain, N.; Pathak, R.; Sandhu, S. Practices In Wound Healing Studies Of Plants. Evid. Based. Complement. Alternat. Med. 2011, 2011, 438056. [CrossRef]

124. Rafiq, M.; Hussain, T.; Abid, S.; Nazir, A.; Masood, R. Development of sodium alginate/PVA antibacterial nanofibers by the incorporation of essential oils. Mater. Res. Express. 2018, 5, 35007. [CrossRef]

125. Vasile, B.S.; Birca, A.C.; Musat, M.C.; Holban, A.M. Wound Dressings Coated with Silver Nanoparticles and Essential Oils for The Management of Wound Infections. Materials 2020, 13, 1682. [CrossRef]

126. Karavasili, C.; Tsongas, K.; Andreadis, I.I.; Andriotis, E.G.; Papachristou, E.T.; Papi, R.M.; Tzetzis, D.; Fatouros, D.G. Physicomechanical and finite element analysis evaluation of 3D printable alginate-methylcellulose inks for wound healing applications. Carbohydr. Polym. 2020, 247, 116666. [CrossRef]

127. Li, T.-T.; Li, J.; Zhang, Y.; Huo, J.-L.; Liu, S.; Shiu, B.-C.; Lin, J.-H.; Lou, C.-W. A study on artemisia argyi oil/sodium alginate/PVA nanofibrous membranes: Micro-structure, breathability, moisture permeability, and antibacterial efficacy. J. Mater. Res. Technol. 2020, 9, 13450-13458. [CrossRef]

128. Lamarra, J.; Calienni, M.N.; Rivero, S.; Pinotti, A. Electrospun nanofibers of poly(vinyl alcohol) and chitosan-based emulsions functionalized with cabreuva essential oil. Int. J. Biol. Macromol. 2020, 160, 307-318. [CrossRef]

129. Jamil, B.; Abbasi, R.; Abbasi, S.; Imran, M.; Khan, S.U.; Ihsan, A.; Javed, S.; Bokhari, H.; Imran, M. Encapsulation of Cardamom Essential Oil in Chitosan Nano-composites: In-vitro Efficacy on Antibiotic-Resistant Bacterial Pathogens and Cytotoxicity Studies. Front. Microbiol. 2016, 7, 1580. Available online: https:/ / www.frontiersin.org/article/10.3389/fmicb.2016.01580 (accessed on 4 October 2016). [CrossRef] 
130. Cremar, L.; Gutierrez, J.; Martinez, J.; Materon, L.; Gilkerson, R.; Xu, F.; Lozano, K. Development of antimicrobial chitosan based nanofiber dressings for wound healing applications. Nanomed. J. 2018, 5, 6-14. [CrossRef]

131. Rieger, K.A.; Schiffman, J.D. Electrospinning an essential oil: Cinnamaldehyde enhances the antimicrobial efficacy of chitosan/poly(ethylene oxide) nanofibers. Carbohydr. Polym. 2014, 113, 561-568. [CrossRef]

132. Singh, S.; Gupta, A.; Sharma, D.; Gupta, B. Dextran based herbal nanobiocomposite membranes for scar free wound healing. Int J. Biol. Macromol. 2018, 113, 227-239. [CrossRef] [PubMed]

133. Mouro, C.; Simões, M.; Gouveia, I.C. Emulsion Electrospun Fiber Mats of PCL/PVA/Chitosan and Eugenol for Wound Dressing Applications. Adv. Polym. Technol. 2019, 2019, 9859506. [CrossRef]

134. Ardekani, N.T.; Khorram, M.; Zomorodian, K.; Yazdanpanah, S.; Veisi, H.; Veisi, H. Evaluation of electrospun poly (vinyl alcohol)based nanofiber mats incorporated with Zataria multiflora essential oil as potential wound dressing. Int. J. Biol. Macromol. 2019, 125, 743-750. [CrossRef] [PubMed]

135. Ge, Y.; Tang, J.; Fu, H.; Fu, Y. Terpinen-4-ol liposomes-incorporated chitosan/polyethylene oxide electrospun nanofibrous film ameliorates the external microenvironment of healing cutaneous wounds. J. Appl. Polym. Sci. 2021, 138, 49670. [CrossRef]

136. Barzegar, S.; Zare, M.R.; Shojaei, F.; Zareshahrabadi, Z.; Koohi-Hosseinabadi, O.; Saharkhiz, M.J.; Iraji, A.; Zomorodian, K.; Khorram, M. Core-shell chitosan/PVA-based nanofibrous scaffolds loaded with Satureja mutica or Oliveria decumbens essential oils as enhanced antimicrobial wound dressing. Int. J. Pharm. 2021, 120288. [CrossRef]

137. Yan, X.; Yu, M.; Ramakrishna, S.; Russell, S.J.; Long, Y.-Z. Advances in portable electrospinning devices for in situ delivery of personalized wound care. Nanoscale 2019, 11, 19166-19178. [CrossRef] [PubMed]

138. Dursun, N.; Liman, N.; Ozyazgan, I.; Gunes, I.; Saraymen, R. Role of thymus oil in burn wound healing. J. Burn Care Rehabil. 2003, 24, 395-399. [CrossRef] [PubMed]

139. de Oliveira, M.L.M.; Bezerra, B.M.O.; Leite, L.O.; Girão, V.C.C.; Nunes-Pinheiro, D.C.S. Topical continuous use of Lippia sidoides Cham. essential oil induces cutaneous inflammatory response, but does not delay wound healing process. J. Ethnopharmacol. 2014, 153, 283-289. [CrossRef]

140. Gunal, M.; Heper, A.; Zaloglu, N. The Effects of Topical Carvacrol Application on Wound Healing Process in Male Rats. Pharmacogn. J. 2014, 6, 10-13. [CrossRef]

141. Süntar, I.; Akkol, E.K.; Tosun, A.; Keleş, H. Comparative pharmacological and phytochemical investigation on the wound-healing effects of the frequently used essential oils. J. Essent. Oil Res. 2014, 26, 41-49. [CrossRef]

142. Costa, M.F.; Durço, A.O.; Rabelo, T.K.; Barreto, R.d.S.; Guimarães, A.G. Effects of Carvacrol, Thymol and essential oils containing such monoterpenes on wound healing: A systematic review. J. Pharm. Pharmacol. 2019, 71, 141-155. [CrossRef]

143. Buyana, B.; Aderibigbe, B.A.; Ndinteh, D.T.; Fonkui, Y.T.; Kumar, P. Alginate-pluronic topical gels loaded with thymol, norfloxacin and ZnO nanoparticles as potential wound dressings. J. Drug Deliv. Sci. Technol. 2020, 60, 101960. [CrossRef]

144. Langeveld, W.T.; Veldhuizen, E.J.A.; Burt, S.A. Synergy between essential oil components and antibiotics: A review. Crit. Rev. Microbiol. 2014, 40, 76-94. [CrossRef]

145. Riella, K.R.; Marinho, R.R.; Santos, J.S.; Pereira-Filho, R.N.; Cardoso, J.C.; Albuquerque-Junior, R.L.C.; Thomazzi, S.M. Antiinflammatory and cicatrizing activities of thymol, a monoterpene of the essential oil from Lippia gracilis, in rodents. J. Ethnopharmacol. 2012, 143, 656-663. [CrossRef]

146. Guimarães, A.G.; Quintans, J.S.S.; Quintans-Júnior, L.J. Monoterpenes with Analgesic Activity-A Systematic Review. Phyther. Res. 2013, 27, 1-15. [CrossRef]

147. Priyadarsini, K.I. The Chemistry of Curcumin: From Extraction to Therapeutic Agent. Molecules 2014, 19, 20091-20112. [CrossRef]

148. Sami, D.G.; Abdellatif, A.; Azzazy, H.M.E. Turmeric/oregano formulations for treatment of diabetic ulcer wounds. Drug Dev. Ind. Pharm. 2020, 46, 1613-1621. [CrossRef]

149. Berechet, M.D.; Gaidau, C.; Miletic, A.; Pilic, B.; Râpă, M.; Stanca, M.; Ditu, L.-M.; Constantinescu, R.; Lazea-Stoyanova, A. Bioactive Properties of Nanofibres Based on Concentrated Collagen Hydrolysate Loaded with Thyme and Oregano Essential Oils. Materials 2020, 13, 1618. [CrossRef] [PubMed]

150. Wasupalli, G.K.; Verma, D. Molecular interactions in self-assembled nano-structures of chitosan-sodium alginate based polyelectrolyte complexes. Int. J. Biol. Macromol. 2018, 114, 10-17. [CrossRef] [PubMed]

151. Kenawy, E.; Omer, A.M.; Tamer, T.M.; Elmeligy, M.A.; Eldin, M.S.M. Fabrication of biodegradable gelatin/chitosan/cinnamaldehyde crosslinked membranes for antibacterial wound dressing applications. Int. J. Biol. Macromol. 2019, 139, 440-448. [CrossRef] [PubMed]

152. Liakos, I.; Rizzello, L.; Hajiali, H.; Brunetti, V.; Carzino, R.; Pompa, P.P.; Athanassiou, A.; Mele, E. Fibrous wound dressings encapsulating essential oils as natural antimicrobial agents. J. Mater. Chem. B 2015, 3, 1583-1589. [CrossRef]

153. Ge, Y.; Tang, J.; Fu, H.; Fu, Y.; Wu, Y. Characteristics Controlled-release and Antimicrobial Properties of Tea Tree Oil Liposomesincorporated Chitosan-based Electrospun Nanofiber Mats. Fibers Polym. 2019, 20, 698-708. [CrossRef]

154. Lam, N.S.K.; Long, X.X.; Griffin, R.C.; Chen, M.-K.; Doery, J.C.G. Can the tea tree oil (Australian native plant: Melaleuca alternifolia Cheel) be an alternative treatment for human demodicosis on skin? Parasitology 2018, 145, 1510-1520. [CrossRef] [PubMed]

155. Rahman, S.M.A.; Nabi, M.N.; Van, T.C.; Suara, K.; Jafari, M.; Dowell, A.; Islam, M.A.; Marchese, A.J.; Tryner, J.; Hossain, M.F.; et al. Performance and Combustion Characteristics Analysis of Multi-Cylinder CI Engine Using Essential Oil Blends. Energies 2018, 11, 738. [CrossRef] 
156. Carson, C.F.; Hammer, K.A.; Riley, T.V. Melaleuca alternifolia (Tea Tree) Oil: A Review of Antimicrobial and Other Medicinal Properties. Clin. Microbiol. Rev. 2006, 19, 50-62. [CrossRef]

157. Sadri, M.; Arab-Sorkhi, S.; Vatani, H.; Bagheri-Pebdeni, A. New wound dressing polymeric nanofiber containing green tea extract prepared by electrospinning method. Fibers Polym. 2015, 16, 1742-1750. [CrossRef]

158. Sugumar, S.; Ghosh, V.; Nirmala, M.J.; Mukherjee, A.; Chandrasekaran, N. Ultrasonic emulsification of eucalyptus oil nanoemulsion: Antibacterial activity against Staphylococcus aureus and wound healing activity in Wistar rats. Ultrason. Sonochem. 2014, 21, 1044-1049. [CrossRef]

159. Sugumar, S.; Mukherjee, A.; Chandrasekaran, N. Eucalyptus oil nanoemulsion-impregnated chitosan film: Antibacterial effects against a clinical pathogen, Staphylococcus aureus, in vitro. Int. J. Nanomed. 2015, 10 (Suppl. 1), 67-75. [CrossRef]

160. Yousefi, I.; Pakravan, M.; Rahimi, H.; Bahador, A.; Farshadzadeh, Z.; Haririan, I. An investigation of electrospun Henna leaves extract-loaded chitosan based nanofibrous mats for skin tissue engineering. Mater. Sci. Eng. C 2017, 75, 433-444. [CrossRef] [PubMed]

161. Cavanagh, H.M.A.; Wilkinson, J.M. Biological activities of Lavender essential oil. Phyther. Res. 2002, 16, 301-308. [CrossRef] [PubMed]

162. Cuttle, L.; Pearn, J.; McMillan, J.R.; Kimble, R.M. A review of first aid treatments for burn injuries. Burns 2009, 35, 768-775. [CrossRef] [PubMed]

163. Hajiali, H.; Summa, M.; Russo, D.; Armirotti, A.; Brunetti, V.; Bertorelli, R.; Athanassiou, A.; Mele, E. Alginate-lavender nanofibers with antibacterial and anti-inflammatory activity to effectively promote burn healing. J. Mater. Chem. B 2016, 4, 1686-1695. [CrossRef]

164. Alam, P.; Ansari, M.J.; Anwer, M.K.; Raish, M.; Kamal, Y.K.T.; Shakeel, F. Wound healing effects of nanoemulsion containing clove essential oil. Artif. Cells Nanomed. Biotechnol. 2017, 45, 591-597. [CrossRef] 